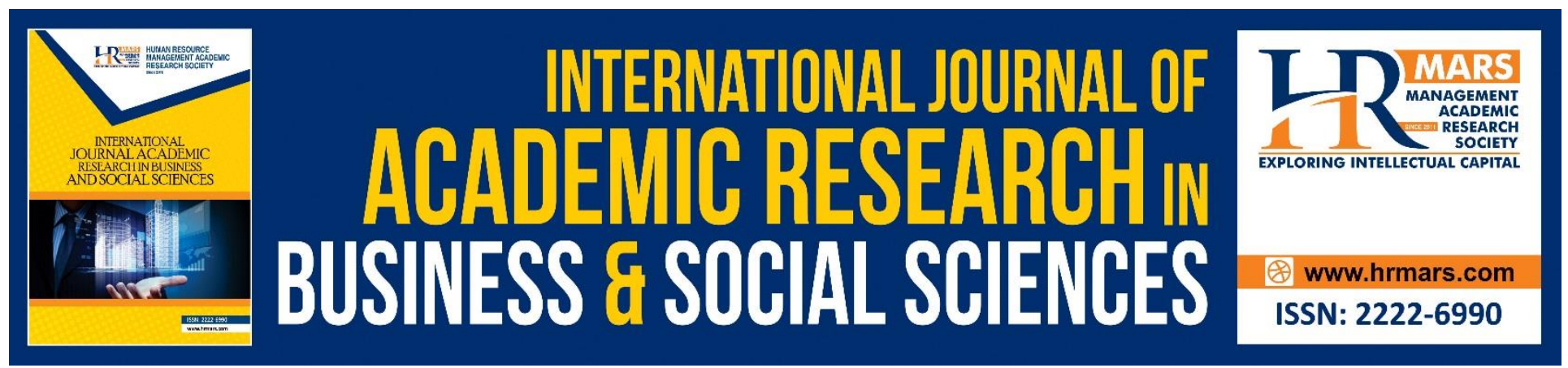

\title{
How Do Self-Directing Work Teams Operate In National and International Contexts and What Are The Benefits Of Them?
}

Mehmet Gunes, David Greenshield

To Link this Article: http://dx.doi.org/10.6007/IJARBSS/v8-i9/4676

DOI: $\quad 10.6007 /$ IJARBSS/v8-i9/4676

Received: 09 August 2018, Revised: 27 August 2018, Accepted: 29 Sept 2018

Published Online: 16 October 2018

In-Text Citation: (Gunes \& Greenshield, 2018)

To Cite this Article: Gunes, M., \& Greenshield, D. (2018). How Do Self-Directing Work Teams Operate In National and International Contexts and What Are The Benefits Of Them? International Journal of Academic Research in Business and Social Sciences, 8(9), 1015-1024.

Copyright: (c) 2018 The Author(s)

Published by Human Resource Management Academic Research Society (www.hrmars.com)

This article is published under the Creative Commons Attribution (CC BY 4.0) license. Anyone may reproduce, distribute, translate and create derivative works of this article (for both commercial and non-commercial purposes), subject to full attribution to the original publication and authors. The full terms of this license may be seen

at: http://creativecommons.org/licences/by/4.0/legalcode

Vol. 8, No. 9, September 2018, Pg. 1015 - 1024

Full Terms \& Conditions of access and use can be found at http://hrmars.com/index.php/pages/detail/publication-ethics 


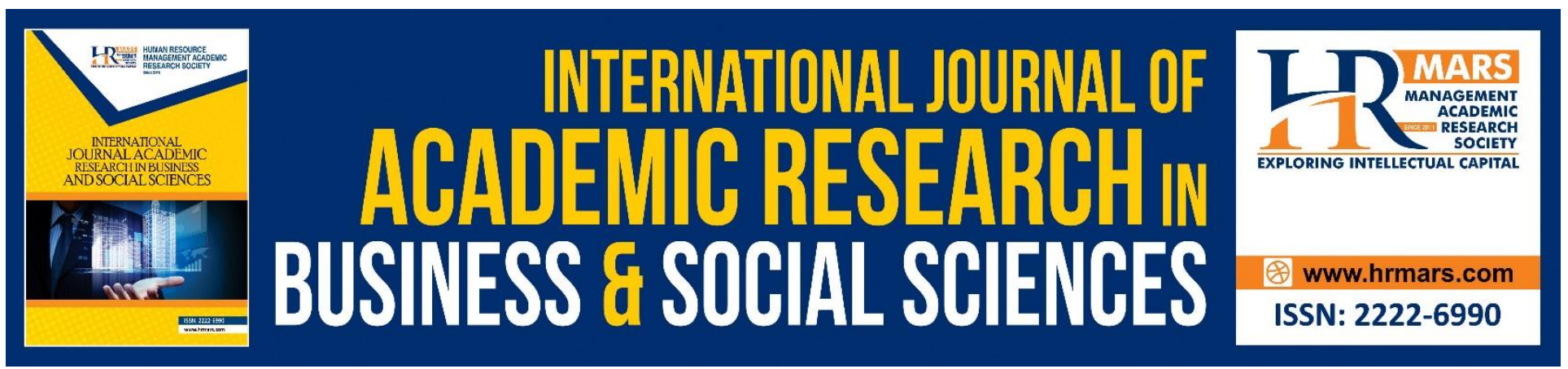

\title{
How Do Self-Directing Work Teams Operate In National and International Contexts and What Are The Benefits Of Them?
}

\author{
Mehmet Gunes ${ }^{1 *}$, David Greenshield ${ }^{2}$ \\ ${ }^{1}$ Adana Science and Technology University, International Trade and Finance \\ ${ }^{2}$ University of Bedfordshire, Business and Management \\ *Corresponding Author: Email: mtgunes@adanabtu.edu.tr
}

\section{Abstract}

The objectives of this research are to understand the meaning of empowerment, to determine its importance in the new workplace, and answer very vital questions in business life. Research questions that are crucial for reaching the aim of the study were prepared. To do so, nine questions are asked to one of the worldwide Japanese Company's executive managers via a comprehensive face to face interview to determine and evaluate the importance of self-management and leadership in the changing world as well. The research also exhibited the particular conclusions on the operation of self-directing work as well as benefit of them in both national and international meanings.

Keywords: Self-Directing Work, Leadership, Work Team, Empowerment, Interviews.

\section{Introduction}

The rapid change in business life is continuous. To be successful in today's business environment, companies need the knowledge, ideas, energy, and having creativity of every employee, from front line workers to the top-level managers in the executive suite. The valuable companies accomplish to reach the target by encouraging their employees to take initiative without prodding, to serve the collective interests of the company without being micro-managed, and to act like owners of the business. It is clear that the training and development of self-directed, empowered work teams is an area that can yield significant increases in productivity and profits within a number of sectors of the economy.

Some executives would like their company to adapt to the changes in the market. These executives believe that the traditional model of organization leads the company to go the bankrupt. A new model of self-management operating under principles established by the new economy and new information technologies is required for a competitive strategy. If organizations are not successful in replacing bureaucracy and command-and-control hierarchy in the market mechanism, self-organizing network structures are going to be replaced by themselves. The self-managing organization is a highly 
INTERNATIONAL JOURNAL OF ACADEMIC RESEARCH IN BUSINESS AND SOCIAL SCIENCES Vol. 8, No. 9, Sept. 2018, E-ISSN: 2222-6990 @ 2018 HRMARS

important issue in transforming traditional command-and-control organizations to new highperformance work systems. (Purser and Cabana, 1998) In the self-managing organization many of the structural configurations can be designed to arrange the company's strategy. Moreover, the selfmanaging organization has the power to self-organize and redesign due to changes in market demands. Another challenge for the companies to the adaption of the self-managing organization is to have long-established beliefs and practices on the distribution of power and authority in private enterprises. Very well-known companies such as American Express, Hewlett-Packard, Microsoft, Nokia, and Toshiba have been very successful in becoming self-managing organizations. Quite a big number of those companies have been using Participative Design and Search Conferences as a method to transfer different parts of their business or their enterprise to the self-managing organizations. Participative Design and Search Conferences are applied to the different industries such as petrochemicals, financial services, airlines, food and beverages, professional services, computers electronics, forest and paper products, health care, hotels, and software companies. Moreover, some agencies in U.S government also used the methods like the Federal Circuit Courts, the Environmental Protection Agency, and the Department of Agriculture's Forest Service. (Purser and Cabana, 1998)

After the 1990s, empowerment became more and more popular strategy for the companies. Today empowerment is applied to quite high number of foundations. It is popular in adult education, management, and human resource development. (Block, 1987; Freire, 1970; Imel, 1999; Inglis, 1997; Thomas and Velthouse, 1990). In the last twenty years, many companies tried to modernize their structure and work proceeding in order to compete and adapted a highly challenging business life. To achieve that the techniques and approaches are namely Empowerment, Teams, Total Quality Management (TQM), and Reengineering are used. Some of the companies that were applied to the techniques and approaches given above achieved to get significant results while many others collapsed or bankrupted. The crucial question is why some companies, which have tried to move from contemporary-change-management and adapt continuous management methods, have failed. The main reason is that employees in the organization or firm did not recognize the importance of the applying the methods as described above and did not realize being the part of the team empowerment. Most of the managers who were responsible for their organizations were not allowed to apply empowerment in their management. In some cases the managers were not involved to sort out any problems that arise in the organization or not asked their opinion, approval and suggestions.

A big number of companies have adapted to new ideas or strategies such as team work and spirit of the team due to effects of the globalization. The main aim of adapting the new strategies was to transform the traditional management system to a modern one. In order to develop the new strategies work, they tried to understand the meaning of the empowerment to employee the selfdirected work team. First of all, they worked out the effect of the empowerment on the employee and employer. The next step was to find out the type of leadership and how to be a good leader. In addition to those, some questions arose straight away such as what are the rules of the leadership and what is the importance of the leadership and their duties? After the 1980's the description of the leadership was given by Yeatts \& Hyten and the best description has been done by Kimball Fisher in 2000's. Fisher highlighted the manager and coach facilitator models discussing the differences and similarity. 
This study focuses on empowerment, the importance of self-directed work teams in the workplace, mission, vision, specific management responsibilities, and leadership in the worldwide companies. To do so, the face to face interview was conducted with one of the global well-known Japanese group company that has revenue of 9.2 trillion yen as well as over 300.000 employees. The discussion have been extended in terms of the following questions' answer; what does the one of the Japanese brand expect by changing from traditional work teams to self-managed teams and what benefits the change will bring to the company? The study can be considered as a case study. The company name will be affiliated as Company ' $A$ ' from now on. The more detailed of the company are given as following; Company A makes up a corporate group consisting of 1.252 companies, including 864 consolidated subsidiaries within Japan, and 656 overseas, and 208 affiliated companies in Japan that use the equity method. In terms of business activities, there are seven business units with revenues of about 9.2 trillion yen and the company's capital is 458.7 billion yen. The Group recruits about 303.887 employees.

Source: Group Corporate Social Responsibility Report (2017-2018)

\section{Methodology}

\section{Research Method and Findings}

Basically, there are two types of data sources, primary and secondary. In this research the primary data analysing have been used. In primary data collection, the data's were collected using methods such as interviews and questionnaires.

On the other hand, secondary data analysis is commonly known as second-hand analysis which is described as indirectly data collection by another source (Malhotra and Birks, 2006). It is simply the analysis of pre-existing data collected in a different way or to answer a different question than originally intended. In contrast to secondary data, primary data comes from observations made by the researchers themselves. This often creates credibility issues that do not arise with secondary data. Common sources of secondary data are generally picked up from social science surveys and government agencies.

The objectives of this research study was to find out the managers' and team workers opinions on self-directed work teams and new leadership in the challenging global environment some of the following questions were asked to team leader and employee':

- What are the most important benefits you expect as part of a self-managed team?

- Considering the PADIE model (Plan, Analyse, Design, Implement and Evaluate), given the nature of your organization and your team, what are the five phases of transition you feel the most critical to your successful transition to a self-managed team? Why?

- What are the key words, phrases, or points that need to be included in your vision and mission?

- What do you think about the specific management responsibilities that the team has to assume?

- What is the different between manager, coach, and facilitator?

- What are the steps or tasks that the team needs to accomplish to meet or exceed the needs of its customers?

- How should the leadership be in the new global environment? 
INTERNATIONAL JOURNAL OF ACADEMIC RESEARCH IN BUSINESS AND SOCIAL SCIENCES Vol. 8, No. 9, Sept. 2018, E-ISSN: 2222-6990 @ 2018 HRMARS

- Should a failed leader be replaced by another leader or should the whole risky formula of leadership, with its inner mythical core, be abandoned?

- What is the best way to work with team leaders to ensure that they are providing what is needed to their teams?

To determine empowerment, the importance of self-directed work teams in the workplace, mission, vision, specific management responsibilities, and leadership for a well-known global company the face to face interviewed were performed. It is worth noting that no additional information and comments were added to the answer of company executive.

Question 1. The importance of self-directed work teams: What are the most important benefits you expect as part of a self-managed team?

Empowerment is a very crucial issue, especially since the 1980s. With the onset of globalization, companies need the knowledge, ideas, energy, and creativity of every employee, from front line workers to the top level managers in the executive suite. The self-managing organization plays crucial role in transforming from traditional command and-control organizations to new high-performance work systems. Many of the structural configurations can be designed to rearrange the company's strategy in the self-managing organization. (Fisher, 2000)

After giving brief description on the self-directed work teams as above, Dr. Williams who is Chief Research Scientist and Laboratory Manager answered the question about the importance of selfdirected work teams. He said:

"We always focus on flexibility which is a significant issue for self-directed work teams. The lack of external pressure makes the team carry out their task effectively."

The same question was answered by Dr. Xu who works for the same company as a researcher. He said:

"Communication and cooperation are very important in self-directed work teams. Another issue that taking into consideration of the spirit of the team in the global business life."

Dr.Albert who also works for a researcher answer was quite interesting;

"The self-managed teams differ from traditional work groups. Employees need to learn new skills and update themselves in order to be successful in a self-managed team. The skills they need to learn will provide them to interact and communicate with each other. Being self- directed work team member is required having personal features such as being open-minded, taking responsibility and risk."

Question 2. The models of transition: A good "road map" can help you change to a self-managed team environment. The transition model, which is referred to as the PADIE model (Plan, Analyse, Design, Implement, and Evaluate) is such a road map.

Given the nature of your organization and your team, which of the five phases of transition do you feel will be the most critical to your successful transition to a self-managed team? Why?

A. Which do you feel will be the most challenging phase?

B. What support do you feel you will need to make a successful transition to a self-managed team?

-From the team itself?

-From outside the team? 
According to the PADIE model, Dr. Williams was answered the most important issue among the five road maps to get successful outcomes.

"Planning is the most critical issue among the five road maps, because If we are not well organized and not to inform the team members regarding taken decision by management level. They may end up not understanding what they need to do. It might lead the team to a big chaos."

On the other hand Dr. Xiulai gave an answer as following;

"Analysing is the most challenging phrase among the five road maps. The team should analyse the management responsibility and should observe whether the management responsibility has been carried out readily or not. In Addition to this, the teams also analyze and represent their ideas whether the necessary trainings are provided in the terms of the management responsibility."

Regarding the five road maps to change to a self-managed team environment Dr.Albert said that;

"Evaluating is the most important issue among the five road maps. The organization should give positive or negative feedback about team member's performance either individually or group. Due to size of the team, the evaluation should be done from time to time for instance, at least every six months intervals. It provides the team members to aware of their situation in the team. It will be guide to recover themselves on their task in the presence of the less performance."

Another question which arises during the interview was asked to Dr.Williams.

What sort of support do you need to make the successful transition to a self-managed team from inside and outside the team?

"The expectation from team is flexible approach to make a transition and obey the rules which are compulsory for transition. However, the expectation from outside the team is to understand the differences. Because, making a successful transition requires a lot of changes and these changes should not be found odd. It should be considered as a part of the timescale of the transition."

The answer given by the second participant Dr.Xu to the same question was slightly different from Dr.Williams. He pointed out that:

"The key points to make a successful transition to a self-managed team are motivation and adaptation. The team gets used to orienting the new transition without suffering any adaptation problems. However, the encouragement should be provided by the management levels."

The last participant Dr.Albert said that:

"Implementation is a major issue to be taken into account to make a transition. In the absence of the implementation of the plan, we can not talk about the successful transition. The feedback and control from the outside team are important"

Question 3. Mission and vision issue: What are the key words, phrases, or points that need to be included in your vision and mission?

From the point of view of the Team Facilitator, a vision issue can be improved to provide focus and guidance for the self-directed team. Table 1 shows the result of the shared self-directed team vision. The reason of the working together in the team provides this vision. The vision statement can be declared in order to prevent misunderstanding and make use of it in the teamwork. 
INTERNATIONAL JOURNAL OF ACADEMIC RESEARCH IN BUSINESS AND SOCIAL SCIENCES

Vol. 8, No. 9, Sept. 2018, E-ISSN: 2222-6990 @ 2018 HRMARS

Vision Statement

People are passionate about their work and making a future for the program.

An environment where people feel:

-valued

- their ideas matter and opinions count

- they have an effect on a shared destiny

A place where:

- diversity is appreciated

-people's creativity is maximized and respected

- everyone has something to offer( authorship)

Table 1: Self-directed team's vision.

Source: Erlick (2002) Case study: "Comparison of motivation for achieving higher performance between self-directed and manager-directed aerospace engineering teams"

However, the mission can be interpreted either as a statement of purpose or something what the team have to do in order to achieve the vision. Basically, it is the unique value of the team to contribute to the organization. (Chang and Curtin, 1994)

Dr.Williams's point of view regarding the point of vision and mission are determined by the following answer.

"I am the member of the research group in Company $A$ and I believe that general goals are more preferable than specifics. However, due to having a research group in Company $A, I$ am experienced that the research takes quite long time to obtain reliable results."

On the other hand, Dr.Xu brings the attention to another side. He led his speech highlighting the importance of the appreciation by the customers. According to him:

"The outstanding quality of work is acquired as a result of having mission and vision. I believe that when the outstanding quality peace of work is represented and appreciated by the customers the mission will be completed."

The third participant Dr. Albert said that:

"As the company's vision is titled "inspire the Next" I believe that creating a prosperous and comfortable society should be the main aim of vision and mission."

Question 4. Management responsibilities: What do you think about the specific management responsibilities that the team has to assume? The following information was given to participants before their answer.

"Chang and Curtin were reported that self-managed teams do not have supervisors. Instead, all team members share the responsibility for handling the management task. Many of these responsibilities such as hiring and discipline problems are best handled during a team meeting. In addition, individuals should do other task such as ordering supplies and coordinating with other work groups. (Chang and Curtin, 1994)"

The given answer regarding specific management responsibility was very interesting. According to Dr.Williams:

"The team has to assume the understanding of different timescales."

However, Dr.Xu said that: 
INTERNATIONAL JOURNAL OF ACADEMIC RESEARCH IN BUSINESS AND SOCIAL SCIENCES Vol. 8, No. 9, Sept. 2018, E-ISSN: 2222-6990 @ 2018 HRMARS

"All of the self-managed team members have training in how to process of learning skills to do many different tasks. As a result of trainings, they will become multi skilled people."

The last participant Dr. Albert shared the nearly the same views of Dr.Xu. He said that:

"Multi-skilled people are able to fulfil the demands of the company in the absence of the person who is supposed to be in charge for specific tasks. Multi-skilled people are required to have understanding capacity and analysing in case of the different situation."

Question 5. The differences of the contribution of the between leader, coach, and facilitator to the team: What is the different between manager, coach, and facilitator?

The common idea of Betsy S. Hersher, Linda B. Hodges, and Janice A. Klein is that there are significant differences between the contributions of the team leader, coach, and facilitator to the team. (Hersher and Hodges, 2004).

Hersher et al. were published a report saying that main responsibility of the team leader is to make sure that resources are enough to produce good quality items or services. In the terms of the contribution of the coach, he/she should watch the progress of the production or services and in case of the observing any mistake or faulty. He/she should involve the circumstances by solving the problems. The behaviour of the coach while he/she is trying to solve the problems should be tough in order to direct of his/her team. The common idea of the authors regarding the type of the coaches is that a coach might be internal, external even a member of family or a person from a professional organization (Hersher and Hodges, 2004).

In addition to Hersher et al., John Heron describes a facilitator as an individual person who is responsible the control or manage the exchange of the information. A facilitator's role is proceeding of the discussion rather than offering advice. Another interpretation of the facilitator's duty is to address the journey, rather than the destination (Heron, 2004)

According to Dr. Williams:

"A leader is the main factor of leading the team successfully. However, a leader obsesses some features such as forward-looking, inspirational, predictive, analyst and having vision. It will provide team leader to analyse and predict possible expectation from the near and further future in business life. However, the coach should ensure that the team has enough training to carry on their work effectively while a facilitator obtains materials or equipment to complete works or services on time." For the same question, Dr. Xu answered that:

"A leader should keep updating the team and motivate people in the team."

However, the view of the Dr.Albert is that:

"The contribution of the coach is to regulate or reform the lack of the performance while a facilitator's is to give the team hand with solving problems."

Question 6. Steps or tasks for the team needs: What are the steps or tasks that the team needs to accomplish to meet or exceed the needs of its customers?

The management of the company or organizations give the empowerment to their staff. After having empowerment they should use their minds, talents and skills to make the organization more successful. There are lots of steps or tasks to meet customer expectation such as customer advocate, trainer, skilled worker, decision maker, problem solver. In the presence of such abilities that would help team member to build personal confidence to reach or even exceed the customer expectations. According to Dr Williams: 
INTERNATIONAL JOURNAL OF ACADEMIC RESEARCH IN BUSINESS AND SOCIAL SCIENCES Vol. 8, No. 9, Sept. 2018, E-ISSN: 2222-6990 @ 2018 HRMARS

"The continuous clear output by the team is the main issue to meet customers' expectation."

The answer of Dr. Xu was differed from Dr.Williams. He pointed out that:

"In case of the good relationship with customer, the team is going to be closer to customer. Resulting good relationship might be the fact to exceed the customer expectations. On the other hand, getting on well with the suppliers will help organizations to get low-cost and good quality stuff."

The answer of Dr. Albert was well agreed with Dr Xu;

"Building up strong and continuous relationship between customers and team are key point to meet or exceed their expectation."

Question 7. The importance of leadership in the global environment: How should the leadership be in the new global environment?

Every enterprise, organizations, or ventures need successful managers for various circumstances. According to Charles Handy' report, a good leader has some specialities such as vision and mission and adds that "a leader shapes and shares a vision which gives point to the work of others." ( Handy, 1989)

During the interview, Dr.Williams made some comments on the importance of leadership in the global environment considering the daily changes of the business life. Due to having competitive and challenging business environment, the business life is changing day by day in the world. To be successful and show very promising progress in today's business environment, companies need to follow up the new technology and adapt themselves. Apart from these, they should have the knowledge, valuable ideas, dynamic and creative employees from front line to the top level managers in the executive suite. However, with the globalization, the definition of the leadership's role has been changing.

Dr.Williams pointed out that:

"In the new global environment, the leaders should improve and renew themselves. However, the adaptation into the dynamic global environment is possible if the leaders are continuously flexible." The other participant Dr.Xu said that:

"It should be focused on the personality and vision of the leaders. The leaders should be honest and looking forward in the global new environment."

Apart from two participants Dr.Albert indicated that:

"The leaders should be fair and broad-minded. These two statements would be useful to accept and tolerate all the various ideas in the new global environment."

Question 8. Role of leadership: Should a failed leader be replaced by another leader or should the whole risky formula of leadership, with its inner mythical core, be abandoned?

According to P.Northouse, leadership in organizational groups or work teams has become one of the most popular and rapidly growing area in theory and practice. Teams are organizational groups composed of members who are interdependent, who share common goals, and who must coordinate their activities to accomplish these goals. Examples of such groups may include project management teams, task forces, work units, standing committees, quality teams, and improvement teams (Northouse, 2004)

Other idea reported by Porter and Beyerlein is that today's organizations are facing rapidly changing conditions with new technology, new structure, global economic competition, and increasing diversity, among other changes. The organizational team structure is one way an organization can 
respond quickly and adapt to these constants and rapid changes in workplace conditions (Porter and Beyerlein, 2000).

In addition to the ideas/approaches of the various authors regarding the importance of the leadership, Dr. Williams added his point of view about the failure of the leader during the management or administration process in a company. The question was that if a leader failed in doing his/her task and this task was given another person with all risk would it mean that the whole risky formula of leadership, with its inner mythical core, be abandoned?

Dr Williams's answer was highly interesting. He said that:

"In order to answer this question, I have to evaluate management policy of the companies. It shows differences from one company to another one. Basically, I want to point out that the answer is neither positive nor negative. It depends on context."

Dr Xu said that

"In order take any decision about replacing the leader, all the conditions and environment should be obtained. The replacement can be oriented the structure of the company as well."

The last participant Dr Albert said that:

"Without knowing structure of the company and skill of the people in the organization, it is not easy to answer this question. "

Question 9. The best way to work with team leaders: What is the best way to work with team leaders to ensure that they are providing what is needed to their teams?

The team leaders support the team not just emotional and also practical. These supports can be provided monitoring the work effectively (giving them the feedback time to time. The condition of having a high correlation between leader and team workers is consulting. Asking team members' ideas and opinions give positive effect on relationship creating brain storm to take a decision or conduct the management. (Kline, 2003)

As a team leader Dr.Williams said that:

"Continuous two-way communication is main issue to work with team effectively. This issue is going to provide awareness of the cases between all the team members and leaders. It will also allow them to exchange their ideas, knowledge between each other."

In addition to continuous two way communication, Dr.Xu said that:

"Two-way cooperation is another issue to work with team effectively. Taking into account two-way cooperation is going to create effective work. However, a leader should have standard of organizing, developing talent and setting work to conduct the management."

The last participant, Dr.Albert said that:

"Collaboration in a respectful way is important to work with team effectively."

It was amazing that three of the participants highlighted the continuity.

The interview participants were interviewed according to the interview protocol located which was designed to address the research questions.

\section{Findings and Results}

The findings of self-directed work teams indicated that the teams contribute to use of a group of spirit to help each other in the terms of the problem solving aspects during the work process. And also the training function in an organization can assist in self-directed work teams. 
The interviewers pointed out that due to globalization, the style of management changed significantly in the workplace. These findings show us that the companies must adapt new technology, knowledge and skills in order to survive in the changing world. However, interviewers indicated that there are differences between traditional leader and new leader in the global environment. The participants of the interview also added that due to changing of the customer's expectation from organizations, team members and leaders improved themselves in the same parallel of customer's expectation for the last decades. In the changing world, decision-making plays a very crucial part in the business life. All the participants highlighted that team members should have some features such as continuously flexible, caring two-way communication and being in cooperation, providing clear output. During the interviews, they shared their experience, knowledge and key points of obtaining successful in the business life. The current work is going to be quite good guidance people who are interested in management.

It is worth pointing out that executives and employees should have a personal mission and vision to reach their individual target. This can be mainly attributed to the importance of self directed work teams and leadership.

\section{Conclusion}

In conclusion, the importance of empowerment in the management has been determined in terms of development with the time. The reasons for using self-directed work teams rather than traditional one has been discussed. The key points of surviving and competing in the very tough business life for the companies and general information regarding self-directed work teams and empowerment have been discussed. The preference of using traditional and self-managing model is linked to globalization.

The definition of leadership and its types were deeply studied. It has been concluded that due to fast changing and challenging global word were the main issue for leadership and its types.

The Solo and team leader type have been compared taking into account both the negative and positive effects on the team performance as well as the leadership-power and leadership-coercion as a function of management. Another aim of the study is to encourage people who would like to have leader position and write a history of success in terms of management.

In the study, one of the primary data techniques namely questionnaire was used during the interviews reaching the application of the self-directed team management.

The use and application of the self-management concept and ideas, rather than traditional ones, had a positive effect on the workers. In other words, referring a secretary as management assistant or team member makes the person feel more confident and more involved handling the cases or circumstances.

All the participants highlighted that one of the biggest issue in order to sort out a problem which arises in the work place is to have a vision and mission. According to the participants, applying continuous flexibility, caring two-way communication, being cooperative, and providing clear output during the management process are the key points of having a mission and vision. Another point is that continuous training is necessary to help team members learn different skills, which will in return provide team members with the chance to become multi-skilled people. According to the 
INTERNATIONAL JOURNAL OF ACADEMIC RESEARCH IN BUSINESS AND SOCIAL SCIENCES Vol. 8, No. 9, Sept. 2018, E-ISSN: 2222-6990 @ 2018 HRMARS

organization, it is very convenient to have such people so that in the absence of one of the team member, they can be replaced with another multi-skilled person.

In addition to interviews, more discussions with all the participants individually were conducted. Based on the Group Corporate Social Responsibility Report (CSR) (2008) the e-learning class (Electronic learning) set up in 2006 and so far nearly 70 group companies have been involved in Japan. The CSR guidebook has been published and distributed to Asian companies and they also wish to hold more conferences to let companies find out about the e-learning system in order to help improve collaboration between each other.

The objective of this research study was to find out the managers' and team workers opinions on selfdirected work teams and new leadership in the challenging global environment. To determine the result of the study a face to face interview were conducted with one of the worldwide company. It was revealed how to apply self-directed work teams and new leadership on a global company. It is believed that such detailed case study will be a guide for researchers and managers.

\section{Footnotes}

This study is a revised version of an MBA thesis submitted to University of Wales Institute, Cardiff in 2009 by Mehmet GUNES.

\section{References}

Block, P. (1987). The Empowered Manager: Positive Political Skills at Work. San Francisco, JosseyBass, First Edition.

Cabana, S., Purser, R. (1998). The Self-Managing Organization. The Free Press, First Edition.

Chang, R., Curtin M. (1994). Succeeding As A Self-Managed Team. Richard Chang Associates, First Edition.

Erlick, K. (2002). Case study: Comparision of motivation for achieving higher performance between self-directed and manager-directed aerospace engineering teams (ProQuest Dissertations And Theses). Pepperdine University, California.

Fisher, K. (2000). Leading Self-Directed Work Teams: A Guide to Developing New Team Leadership Skills. McGraw-Hill, First Edition.

Freire, P. (1970). Pedagogy of the Oppressed. New York: Herder and Herder.

Handy, C. (1989). The Age of Unreason. Harvard Business School Press, First Edition.

Heron, J. (2004). The Complete Facilitator's Handbook, Kogan Page, Fourth Edition.

Hersher, B. S., Hodges, L. B. (2004). Career Success in Healthcare Information Management. Healthcare Information and Management Systems Society.

Imel, Susan. (1999). How Emancipatory is Adult Learning? Myths and Realities. ERIC Publications, https://files.eric.ed.gov/fulltext/ED436663.pdf.

Inglis, T. (1997). Empowerment and Emancipation. Adult Education Quarterly, 48(1), 3-17.

Kline, T. J. B. (2003). Teams that lead: A Matter of Market Strategy, Leadership Skills, and Executive Strength. Lawrence Erlbaum Associates, First Edition.

Malhotra, K.,N., Birks, D., F. (2006). Marketing Research: An Applied Approach. Financial Times/ Prentice Hall, Third Edition. 
INTERNATIONAL JOURNAL OF ACADEMIC RESEARCH IN BUSINESS AND SOCIAL SCIENCES

Vol. 8, No. 9, Sept. 2018, E-ISSN: 2222-6990 @ 2018 HRMARS

Northouse, P. G. (2004). Leadership:Theory and Practice. Sage, Third Edition.

Porter, G., Beyerlein, M. (2000). Historic Roots of Team Theory and Practice. In M.M.Beyerlein (Ed.), Work Teams: Past, Present and Future, Dordrecht.

Thomas, K. W., \& Velthouse, B. A. (1990). Cognitive elements of empowerment: An interpretive model of intrinsic task motivation. Academy of Management Review, 15(4), 666-681.

Yeatts, D. E., Hyten, C. (1998). High Performing Self-Managed Work Teams: A comparison of theory to practice. Sage, First Edition. 